\title{
Socio-Cultural System of Duri Community of Enrekang Regency South Sulawesi
}

\author{
Abd. Rahman Pilang \\ "45" University of Makassar \\ Makassar, Indonesia
}

Received: July 12, 2013

Accepted: August 28, 2013 Published: February 26,

2014

doi:10.5296/iss.v2i1.5109

URL: http://dx.doi.org/10.5296/iss.v2i1.5109

\begin{abstract}
This is a sociological study discussing and describing socio-cultural system of Duri community of Enrekang Regency South Sulawesi. Data are obtained through in-depth interview, observation, documentation analysis. Methodology used is qualitative descriptive approach. It focuses more on the observation and in-depth interview towards phenomenon and expert informants having wide knowledge about situation at that time. The findings conclude that Duri Community has had a well-arranged socio-cultural system. Far before history began, "Duri Kingdom" has already been found in the area. Duri community paid intensive attention on leader recruitment. They view a leader as a figure who has a very crucial position in the life of community. Leader is identical with benefit, and prosperity of the people.
\end{abstract}

Keyword: socio-cultural system, Duri community, Enrekang regency 


\section{Macrothink}

\section{Introduction}

Basically human is a social creature. It is nearly impossible to find man without community as a medium to grow and develop. Every community has socio-cultural system as a life principle. The socio-cultural system has more influence towards the development of one's character, personality, even leadership. As a leader, for sure the characteristic and personality, and leadership are much influenced by community culture (socio-cultural system).

One's leadership style is very much determine by his basic personality and socio-cultural system where he live so we can say that every action and policy taken by a leader reflects cultural value upheld by community where he is one of its members, and the characters are innate. Leader of innovative, creative and commanding can be an agent of socio-cultural transformation; even can be determinant factor for community stability.

One of some communities in Enrekang Regency South Sulawesi interesting to be discussed its socio-cultural system is Duri Community. Duri is not only the name of a region but it has already become the name for a sub ethnic of Massenrempulu tribe. People coming from this place prefer identify themselves as people of Duri, rather than people of Enrekang, as commonly known by residents of South Sulawesi. This study of sociology is aiming to observe and describe socio-cultural system of Duri community.

\section{Research Methodology}

\subsection{Research Location}

This research is conducted in Duri of Enrekang Research South Sulawesi Province, in the eastern part of the region is Latimojong mountain with its peak Sinaji and Batu Bolong which separate between Enrekang, Luwu, and Tana Toraja regency. In the slope of Batu Bolong peak is the center of Duri Kingdom that is in a hill commonly known as Buntu Duri.

\subsection{Nature of the Research}

This is a qualitative research aiming to observe and describe socio-cultural system of Duri Community through qualitative approach. Qualitative approach is selected in this study by the consideration that the approach is more appropriate to study things of phenomenon and reveal hidden facts behind the phenomenon (Corbin Et Straus, 1967 and Hasniati, 2006). Qualitative research design is flexible, unorganized and go with the flow, for example in the purpose, subject, sample, data source, etc.

\subsection{Research Instruments}

Main characteristic of qualitative research is the data collection technique used, the techniques are participative observation technique and interview technique. By those data collection techniques, the role of the researcher is determinant for the whole research (Moleong, 1996). Therefore the main instrument in the research is the researcher itself.

In the qualitative research, researcher's position is quite complicated. He/she is the researcher at the same time as the planner, analyzer, data interpreter and reporter of the research result. Therefore, definition of research instrument here is already appropriate, noting that the 
researcher is the center of the research process. (Nasution, 2003)

\subsection{Research Informants}

Research Informants meant here are they who are expected to provide information about the subject of the research. Some of the informants are still reside in Enrekang Regency and some others have moved and stayed in outside areas such as Pinrang, Makassar and Jakarta Regency. Whereas, procedure to decide informant is done based on the need (purposive technique), as well as the number of informants, determined based on the surfeit of information obtained.

\subsection{Data Collection Techniques}

Data collection technique used in the research is

a. Observation, in which data collector conduct direct observation on the research location, by direct recording, picture or video documentation to support the research result. Participative observation technique is not a single method. It still needs other techniques such as in-depth interview technique (including interview of life history) and documentation technique.

b. Unstructured in-depth interview. The technique is performed through direct interview between interviewer and interviewee (Arikunto, 1996). Then it needs direct interaction. This is the strength which is at the same time the weakness of this technique (Kerlinger, 2000).

c. Documentation analysis, participative observation and in-depth interview (including interview on life history) can be completed by literary studies such as analysis of autobiography, memoir, diary, personal letters, court notes, newspaper news, magazine articles, brochures, bulletins, and photos (Mulyana, 2006).

d. Mulyana (2006) emphasized that historical document is important source for qualitative research. Both said, as part of field method, researcher can analyze historical documents and other secondary sources, as most situation studied have its own history and those documents explain partial aspect of the situation.

\subsection{Data Analysis Techniques}

Before analyzed, data collected are arranged systematically or grouped based on the need, primary data, secondary data, or complementary data. The data are analyzed, then drawn specific conclusion followed by interpretation and the position of specific conclusion of the research result towards grand concept: whether it is sharpening, modifying, or enriching the concept.

Noting that it is a qualitative research, so analysis was done starting from researcher enters the real field (Salam, 2000). It means that analysis last throughout the research process, or in another word it is ongoing during data collection (Bungin, 2006). 


\subsection{Research Objectives}

The researcher was conducted to get reflection on socio-cultural system of Duri community, of Enrekang Regency South Sulawesi Province.

\section{Result and Discussion}

\subsection{Kingdom of Duri}

Duri is nothing but a hill in the slope of Latimojong Mountain (Batu Bolong peak), precisely name named Buntu Duri. Buntu in the language of Duri means mountain, while duri is spine. The story of how Duri was named can be found in the story of Lontara Duri. A story about kingdom of Duri was taken from Transkripsi Lontarak Duri (Rampunan Kada) by Syukur Abdullah which was published in 1986. To obtain information on everything related to the origin of a community or ethnic, there is usually a story told through generation or research report of the previous experts. Koentjaraningrat (1981) stated that in the practice, to search for information about prehistoric time of a nation, an expert only need to read reports on archaeological research and observation of prehistoric experts about general place commonly used as residential and the origin of the related nation. Based on the quotation, so to conduct research on the origin of Duri Kingdom, the researcher referred to Lontara' Duri transcript as mentioned before.

In the era when there were monarchy system in Indonesia, there has been already some kingdoms in Enrekang Regency which each of them was independent, they were sovereign (onafhankelijk), they were: Maiwa, Enrekang, Duri, Kassa, and Batulappa. Those kingdoms were under one federation that was "Federation of Massenrempulu or Massere-Bulu" (Morris, 1992). Then Duri Kingdom was separate into three kingdoms, they were Malua Kingdom, Alla Kingdom and Buntu Batu Kingdom. Those three fragmentations of Duri Kingdom were also under one federation known as Tallu Batupapan. From those five kingdoms including Massenrempulu, Duri Kingdom was the most dominant and had great influence in the community. Factors causing Duri Kingdom to be the dominant are: "it has the largest area under its authority, the oldest of all, the center for economics activities, and has a complete government system".

In Lontara' Duri (Abdullah 1986) it was told that at the past time it was grown so many plants called as "Cena'Duri". It has sweet and delicious taste. Since then the name Duri was started to be used for as a name for a region between Mountain of Batu Bolong in the east, one of the peaks of Mountain of Latimijong and mountain of Bamba puang in the west.

Recently Duri is not only the name of a region but it has already become the name for a sub ethnic of Massenrempulu tribe. People who come from this place prefer identify themselves as people of Duri, rather than people of Enrekang, as commonly known by residents of South Sulawesi

The first king of Duri kingdom is Nene' Matindo Dama'. In the beginning of the government of king or Pake everything was just as expected. However, then it occurred a happening caused Pake could no longer function as before. Due to the life demand, Pake Nene' Matindo 
Dama' very frequently leaved the village. In some traditional ceremonies sometimes Pake was not there.

People then thought that it had to be solved as soon as possible. To overcome this problem, then people of the community held discussion under Tetua Adat or More (the chief of the village before Pake). This gathering in the Duri custom was called as "Mangtongkonan", a traditional habit which reflects practice of democratic principle at that time.

In the discussion it was revealed that the king had an important role for his people, moreover there were so many problems faced by the people day by day due to the intensive communication between villages. From the discussion then formed Sulle Batang (King substitution) and Pabbicara (Implementing Governance).

By the existence of Sulle Batang and Pabbira, then government structure of Duri Kingdom consisted of More as village chief which through the development in the government structure then became Pemangku Adat (Indigenous Stakeholders) (Adat), and Pake as the King. While function of Sulle Batang is as a substitution whenever the king is unable to present, whereas Pabbicara is as an implementing government. This whole structure was as a result of the intelligence of the leaders in the village at that time in the effort to realize the wishes and interest of the people as part of social system.

The procedures for the change of every leadership status were all through deliberation and based on descent. It means if the leader in the position died or quit because of the fault or resign, then the replacement must be decided through musyawarah (deliberation) of the older people in the custom. This structure was modified and getting complete along with the development of local civilization. In the process of modification in the social system of Duri community, More has the biggest role and distribute most ideas to solve any problem raised among people.

In selecting a new leader it is not allowed to deviate from the "principle of descent". It was well understood noting that Pake (the fist king), in this case Nene' Matindo Dama' it was told in the folklore that he was a descendant of extraordinary men, " mellao jao mai langi" "(down from the sky). Maybe this is what is called as Tomanurung in indigenous culture of Bugis Makassar. He was called as Tomanurung as many people give him because a lot of people give reward and glory to him so that he considered high. This is because who was called as Tomanurung, have the ability not possessed by the majority" (Rahim, 1992).

Based on the story above, we have some points to study. The story that Nene' Matindo Dama' and his wife Cirinna Sambo Langi'come from the sky, we need to interpret it. In the past time, people of the region mostly stayed on the hill of stone, it is known from a folktale that Nene' Matindo Dama' came from the peak of Batu Bolong and Cirinna Sambo Langi' came from the peak of Bamba Puang. We need to know that the confluent of Mata Allo river flowing under the foot of Bamba Puang one of the upstreams is from Sinaji (Uluwai) and one from Batu Bolong. The saying man down from the sky means that both of them c ame from the highest peaks, which are Batu Bolong and Bamba Puang.

Another lesson taken from the story of the origin of king of Duri, is that when Nene' Matindo 


\section{Macrothink}

Dama' prosed Cirinna Sambo Langi' to become his wife, the main consideration was "character" and values that are held in the form of advice or message from their parents, not because of the beauty or wealth. Similarly when Cirinna Sambo Langi received the proposal of Nene' Matindo Dama' her main consideration was that 'Nene' Matindo Dama' very honest and his capability to uphold the mandate".

Character, honesty, and commitment to uphold mandate are the main values for both of them. Those values become the principle for generations of Duri ethnic through generations. Similarly, selection of Nene' Matindo Dama' as Pake for his people, the consideration was the charisma of a light beam physical appearance (aura) which appears on him when first time met with people in the village. People requested Nene' Matindo Dama' to became Pake proves that the people of the region yearn the existence of a figure for role model and to be followed his command. The saying "Madoangkan ke deen tau laan kampong kikita ambe', nadeen kipeundii boko'na, nadeen tomo kipesa'dingngi kadanna" (we want in this village we have someone to become our parent, to become role model and we follow what he said) is a saying about the people miss to the existence of a leader figure who can be a role model and his command can be heard by the people. The statement is a willingness to be organized in the social system, an expression of yearning to the presence of a leader who has a commendable traits and authoritative. This means that the existence of government is the basic of human being. Communities in the area of Duri already had an organized social system since long ago and had a leader who is respected by all citizens A figure such as Nene' Matindo Dama' has been long waited, so when met him, then people were inspired and thought that they needed a figure of a leader. Every leadership selection whether it is Pake, More, Sulle Batang or Pabbicara, all are decided through deliberation by representation system. The stipulation of the place for deliberation, which was called as"Pattawang" (Abdullah, 1986) showed that Duri community has applied principle of deliberation to take decision, indicated that the practice of democration has been there. It is not exaggerating to say that the system created by the Indigenous Stakeholders at that time it was due to their intelligence.

After the coming of Islam in Tana Duri brought by troops from Bone when attacking kingdoms of Massenrempulu including Kingdom of Duri, there were addition in the government structure named Syara', handling marriage and other things based on Islam.

Therefore, it is a mixture between Islamic teaching and custom (animism and dynamism) which is still clearly seen in the daily life of Duri people.

\subsubsection{Government Structure}

Development in the government structure after Duri Kingdom was divided into three of the similar state kingdoms and was continually undergo improvement. Вапиа sit in a strategic position in the government. Ambe' Banua that perform deliberation to select the king to be, determining criteria from the king to be, leading traditional ceremony to overcome problems among the community. From the analysis we can conclude that "Duri commentary has long implemented regional autonomy system" (Iqbal, 2000). In another word s" Duri community is a tribe existed in South Sulawesi which has their own culture and language" (Arnus, 2000), 
different from those of its neighborhood regions, such as Toraja, Bugis and Mandar.

\subsubsection{Leadership Selection}

Based on the data collection report of Historical and Archeological Enrekang Regency issued by (Diknas, 1986) it was stated some requirements and procedures of leadership selection (King, Sulle Batang, Pabbicara and Adat Banua). If king or Pake, and indigenous stakeholders and other status holders in the kingdom when the king died or resign, soon held deliberation (mengtongkonan) in Balairung (Pattawang) to discuss who meet the requirements among the descendants.

And the requirements and criteria (Makkulasse, 1986) set for the selection in the era of past time kingdom in the various community in South Sulawesi community including Duri community, are such as followed: (1). Messappi Dewata Sewwae (believe in One Almighty God); (2). Nini-Nipi (have good character and noble character); (3). Wai Suappi (have sincerity); (4). Magattang (honest);

Those above requirements change over time due to the development in the community. At the beginning when people asked Nene 'Matindo Dama' to become a figure for a role model and a guidance to be listened the advice and consideration more based on the physical criteria that is aura (charisma).

In order to maintain those criteria so the Indigenous Stakeholders proposed the descendants (iyapa maccolo to wai kedeen kalohna) to replace Pake or King when he pass away or resign, water will be able to flow if there is a channel. Channel meant here is the descendants, as for it was believed among Duri people that water will not turbid if it come from clear well. It was meant in order the next leader continue to have an advantage over the average person.

The provision does not seem democratic, but the process of determining the leader still takes democratic ways. The existence of Balairung (Pattawang) and institution of "mangtongkonan" (deliberation) is the proof of democratic process in the selection of leader.

Requirements that arise later were the economic consideration of the candidate. There was a saying among Duri people:"Membulawanni to salaka ke to deen paui", if stated by a nobleman or wealthy man has high value compared if the idea stated by a man of the poor.

Thus the last requirement based on the consideration to keep the selected leader to have prestige. Measurements of the wealthiest at that time are livestock and farm land. Who possess most livestock mainly buffalo and wide fertile farm land, he/she is considered as wealthy men.

In relation with criteria based on the wealth consideration, then decide one requirement to carefully maintain in selecting leader is that the leader to be is not materialistic and greedy (te'da na maulklak). Maullak means, "Not greedy when facing food". Therefore, in every traditional ceremony, whether it is related to the death, or thanksgiving for the harvest time, or any other traditional ceremony, Ambe' Kampung or Pemangku Adat (Indigenous Stakeholders) are not allowed to eat before other people present in the ceremony have finished eating. 


\section{Mll Macrothink}

The meaning of this character is to prevent the condition where the indigenous stakeholders are full when the people are hungry. Leader in Duri community did not think of what will be eaten for tomorrow, but they think whether the people have anything for eating tomorrow.

This character is already in the honest figure. In the culture of Duri honesty is upheld. Leader is identical with life and prosperity. Leader must be one with honesty and strength to hold mandate of the duty. If leader disobey "aluk" (rules of the custom) means disaster for "lolo tallu" (men, animals and plants). The rule is quite similar with a saying from a culture of Bugis people "Aju maluru'emi riyala parewa bola (only straight wood can be used for a foundation of a house)" (Machmud, 1994).

Intelligence factor which is the common requirement for the recent leadership, also become the consideration. It is only this is not explicitly stated in the criteria determined by custom. But, it is frequently known term in the deliberation "malando tanggahna", means the consideration is wide and deep knowledge. It is also frequently heard "macca taunna, apaiyya te'da uki' laan ba'tangna" (a figure of intelligence but there is no writing in his stomach). This means a figure that is known as a man of intelligence but having narrow knowledge and consideration, not wise enough and apriory (Suriasumantri, 1990).

While for the procedure of leadership selection of all levels in the government at that time, there have been in social institution to organize it. Pattawang, mangtongkonan, mangmesa' kada are institutions established for the purpose. One of the procedures determined by Indigenious Stakeholders is based on the descent (iapa namaccolo to wai ke deenni kalohna, te'da na wa'ding mencepak apaiyya lamale tuka'). Meaning of the statement is that new water will be able to flow if there also there available the channel, cannot flow aside or even more flow up. The meaning is that the selection of the replacement for the king will run smoothly if there is a channel and the channel meant here is on the base of descendant. The requirement also reflects that at the beggining Custom has higher status than King. Custom is the one to point the King (Ada' pacindokkoi to Pakejio Batu Ariri).

If we pay close attention to the criteria and procedure of leader selection of Duri people during the monarchy system, practice of democration has already seen in it. So it was already fit that if the Indonesian people set their own democracy that is adopted from an already practiced pattern by the ancestors of Indonesia in the past.

\subsubsection{System of Government}

At the beginning, the existence of king as the highest commander in Duri Kingdom system of government, Pake or King to sit as aleader of the great, for a role model whose advice to be listened. They are considered as to represent of God which "dianna bulawan (have to been kept)". And the implementation of the government is Pabbicara.

The government structure has modified based on the need, for example the establishment an institution for deliberation known as "mangtongkonan", and built a big house for a place of the deliberation called as "Pattawang" (almost similar with a building for House of Representative in the current era). In the deliberation they refer to the rules agreed together before. It shows that law is a matter of life, meaning that principle of "Legal State 
(rechtstaats)" was already practiced at that time. This fact is similarly with a philosophical principle of Wajo people that say “ Maradeka to wajo'e, ada'emi napupuang”.

It is conceivable that at that time the founder of the kingdom are very smart as evidenced by their ability to build a system even they are capable of setting rules in order to maintain the system they created. They have thought about the importance of the "chek and balances" system in the government. Means they have thought the danger if the government is on the single hand. If then there are deviations from the system, it is more due to the influence of individuals who served as King or Indigenous Stakeholders. Modification exists due to the interactions between kingdoms outside Duri kingdom.

\subsection{Belief System (Religious System)}

People of Duri have admitted and believed on the One Almighty God. Nene' Matindo Dama' in advising his children used to mentioned "naelohna to Ampu Padang", which means, "as the will of the owner of nature (God) ". In making decision related to the people always refers to the will of Ampu Padang.

Almost every traditional activity has religious meaning. King or Custom was functioning based on the belief that it is a will Ampu Padang. It was why the status holders were very carefully held the mandate given. Betraying the rules of the custom (ntengkai aluk), could bring anger of Ampu Padang (God) and it means disaster. The term Ampu Padang in the dinamic of belief system of the people at that time then called as"Dewata".

\subsection{Social Stratification}

The existence of layer system in the community was based on the something of pride. Because every community has something to be appreciated, so it is almost no community without social stratification, even country that adopt socialist/communist as the principle (Soekanto, 1986).

When Duri community did not implement monarchy system yet, there has already a social stratification in the villages. The stratification was still very simple and yet based on certain consideration, but it was more spontaneous and based on the role in the social life (community). In the beginning of the monarchy system then social stratification changed to: king and custom, class of ambe'ambe' kampung, and common people. So, there are three social classes they are class of King/Custom, class of Ambe-Ambe Kampung (chief of village), and class of common people. Meanwhile, hamba sahaya (slave) did not exist yet.

Slavery existed when king needed people to help raising livestocks and cultivating farm land, but it was not named as slave. He was just a person who voluntarily served the king. Once people began to grow and the government has regularly settled so it was newly emerged what is known as the bottom layer (slave).

The layers or social classes that exist in the culture of Duri, are as follows: (1). Nobleman and custom; (2). Commoners (parengnge'); (3). Slave (kaunan). 


\subsection{Kinship}

In Indonesian community it is known some kinship systems or kinship. Mainly there are two big kinship systems in the in cultural group or community, they are bilateral kinship and unilateral kinship. Unilateral kinship is divided into two types they are patrilineal and matrilineal. Bilateral kinship counts family relationship from father's side and mother's side (both sides), also commonly called as parental kinship. While unilateral kinship counts family relationship only from one side. "Depend on the way of counting, whether it is from father's side or mother's side. These systems bear patrilineal and matrilineal kniship". Patrilineal counts family matters from the side of father. Whereas, matrilineal kinship counts family matters only from the side of mother (Soekanto dkk, 1981).

If we look closely on the marriage and heritage share system of Duri community, it is clearly seen that it belongs to bilateral kinship, which count from father and mother line. Those who are in the family ties are allowed to married. Marriage system can be endogamy or exogamy. If found any member of the community engaged in marriage of endogamy, the consideration are to keep the pure blood (descent) mainly in the family of nobleman, and keep inheritance of the wealth.

\section{Conclusion}

Based on the explanation on the previous discussion in this writing, it can be concluded that Duri community has had an organized social system. Far before history began, "Kingdom of Duri" has already found in the area. Duri community pays special attention about leader recruitment. For this community, a leader has a very crucial position in the life of the community. Leader is identical with benefit and prosperity of the people; it determines the development of "Tallu Lolo (human, domestic livestocks, and plants)".

\section{References}

Abdullah H., \& M. Syukur. (1986). Lontara’ Duri (Rampunan Kada). Makassar: Hasanuddin University.

Abdullah H., Syukur, M., Ambo, G., \& Hasan B., (1987). Lontara' Enrekang owned: Puang La Sallang a degree Puang Tobalu Pabbicara Last Enrekang. Makassar: Hasanuddin University.

Arnus. (2000). Massen rempulu language. Delivered at the Anniversary in Enrekang Ke-4l. Enrekang 14 February.

Hasniati. (2006). The flow of Philosophy and Public Admin istration Research methodology. Journal of Public Administration, 75, 35.

Iqbal, M. (2000). As an Authorized Cultural Perspective towards Development of Regional Autonomy. Presented at the Seminar in the framework of 41st Anniversary Enrekang. Enrekang 14 February.

Kaelan. (1985). Approximately Pasncasila Formulation Process of the State and the Constitution of 1945. London: Liberty. 


\section{Macrothink}

Issues in Social Science ISSN 2329-521X 2014, Vol. 2, No. 1

Kerlinger, F. N. (2000). Principles of Behavioral Research. Yogyakarta: Gadjah Mada University Press.

Koentjaraningrat. (1985). Introduction to Anthropology. New York: New Script.

Limbugau, D. (1993). Islamization in the Kingdom of Duri. Presented at the Department of History and Archaeology seminar on May 5.

Machmud, A. H. (1994a). Silasa, Collected Wisdom Bugis-Makassar. Makassar: New Centra Bhakti.

Ministry of Education and Culture. (1979). FIRO. Jakarta: Director General of Higher Education. Normalization of Campus Life Project.

Moleong, L. J. (1996). Qualitative Research Methods. Bandung: Teens Rosdakarya.

Mulyana, D. (2006). Qualitative Research Methodology New Paradigm of Communication Sciences and Social Sciences. Bandung: Rosdakarya.

Rahim, A. R. (1992). Core Values Culture Bugis. Ujung Pandang: Hasanuddin University Press.

Ritzer, G. (2005). Modern Sociological Theory. Jakarta: Prenada Media.

Soekanto, S. (1983). Sociological Theory of Social Change. Jakarta: Ghalia Indonesia.

An Introduction to Sociology. (1986). Jakarta: Rajawali.

Soekanto, S., \& Basuki, A. (1981). Cultural Anthropology. Jakarta: Rora work.

Suriaeumantri, J. (1990). Philosophy of Science An Introduction to Popular. Jakarta: Pustaka Sinar Harapan. 